\title{
Ripening of Montecristo Bananas
}

\author{
F. Sanchez Nieva, I. Hernández, and C. Bueso de Viñas ${ }^{1}$
}

\section{INTRODUCTION}

Banana production in Puerto Rico is limited to supplying the fruit for the fresh market. Several ripening plants are in operation where the fruit is ripened under controlled conditions. The fruit harvested is the Montecristo cultivar which is grown mostly in the highlands together with coffee. Fruit quality has been observed to vary throughout the year. It has also been observed that the ripe fruit reaching the consumer many times is of fairly poor quality.

Most ripening room operators have developed the ripening schemes based on published information and on their own experience, but no thorough study has been conducted to determine the best ripening treatments for the bananas locally produced. This report deals with a study conducted to determine the best ripening treatments for the Montecristo bananas in an effort to up-grade the ripe fruit reaching the consumer and supply fruit of adequate ripeness for processing.

\section{REVIEW OF THE LITERATURE}

The methods for ripening bananas have been reviewed by von Loesecke and Simmonds $(1,2) .^{2}$ The requirements for banana ripening rooms and instructions for ripening stem fruit and tropical boxed fruit have been published by the Fruit Dispatch Co. (B). In the United States three methods are generally used for fast, medium, and slow ripening. Von Loesecke and Simmonds $(1,2)$ indicate that for fast ripening, the fruit is ripened at $68^{\circ} \mathrm{F}$. at a relative humidity of 90 to 95 percent, with 2 or 3 dosages of ethylene applied at 12- to 24-hour intervals, no ventilation being used until the fruit colors. For medium ripening, the same procedure is used, but the temperature is lowered to $64^{\circ} \mathrm{F}$. For slow ripening, the fruit is held at $58^{\circ}$ to $60^{\circ} \mathrm{F}$. at a relative humidity of 90 to 95 percent, ethylene is applied as for fast ripening and ventilation providing 3 or 4 air changes per hour is practiced until the fruit colors.

For Gros Michel and Lacatan stem fruit, the following treatments are recommended by the Fruit Dispatch Co. (3): For fast ripening (4 days), the

1 Technical Director, Assistant Chemical Engineer, and Assistant Food Technologist, respectively, Food Technology Laboratory. Agricultural Experiment Station, Mayaguiez Campus, University of Puerto Rico, Rfo Piedras, P.R. The authors wish to express their gratitude to G. Colom Covas and R. Guadalupe of the staff of the Food Technology Laboratory for the assistance given in the field experiments.

Italic numbers in parentheses refer to Literature Cited, pp. 282-3. 
room controls are set for a pulp temperature of $64^{\circ} \mathrm{F}$. and ethylene is applied immediately after the fruit is hung in the ripening room. Humidifying nozules are turned on and the rooms are closed for 24 to 30 hours. At the end of this period the nozzles are turned off, and the room is ventilated for a.15- to 20-minute period. When the peel is beginning to show color, the temperature is reduced to $60-62^{\circ} \mathrm{F}$. until the desired cutting color is reached. To produce medium ripening ( 5 days to color 4 ), the same procedure is used, but the temperature is adjusted to a pulp temperature of $62^{\circ} \mathrm{F}$. For slow ripening (7 days), a temperature of $60^{\circ} \mathrm{F}$. is used until the desired cutting color is obtained.

In the United Kingdom, for the Gros Michel fruit (E), a temperature of $70^{\circ} \mathrm{F}$. at high relative humidity is maintained for 1 or 2 days, and then lowered to $65^{\circ} \mathrm{F}$. Ethylene is used as needed. For the Cavendish group the initial temperature is adjusted to $72^{\circ} \mathrm{F}$. and then lowered to $65^{\circ} \mathrm{F}$.

In Australia, different temperatures are used for summer and winter fruit $(2,4,5)$ for the Cavendish group. During the summer, the fruit is ripened at $68^{\circ} \mathrm{F}$. and 85 percent relative humidity, and during the winter at $66^{\circ} \mathrm{F}$. Ethylene or coal gas is used to accelerate ripening, being applied twice daily until ventilation is started at the first sign of color.

Chemical and physical changes during ripening have been thoroughly discussed by von Loesecke (6). Ethylene must be used as a ripening stimulus with green fruit, and is generally used at the rate of 1 cubic foot per 1,000 cubic feet of room space. The first visual sign of ripening is the change in color from green to yellow. Color charts for bananas at different stages of ripeness are given by von Loesecke (6), and appear also in ripening rooms operators manuals ( $(3)$.

Changes during ripening are best followed by the changes in carbohydrates. The starch disappears with the formation of nonreducing and reducing sugars. Data presented by von Loesecke (6) show that different varieties of bananas show definite characteristics on the proportions of reducing and nonreducing sugars during ripening. As the fruit ripens, the moisture content of the pulp increases, increasing the value of the pulp:peel ratio. Soluble pectin increases and protopectin decreases. Titratable acidity increases reaching a peak and then declines; $\mathrm{pH}$ decreases. The tannin content also decreases. Hulting and Proctor (7) studied the change in volatile constituents of the banana during ripening, storage and processing, and reported differences in the constituents found due to differences in the method of ripening.

Besides the conditions used in the ripening process in regard to the use of ethylene, temperature, and ventilation, several other factors such as clonal characteristics, season in which grown, stage of development at time of cutting, and infection with leaf spot (Cercospora musae) affect the ripening 
characteristics. Simmonds (8), refering to the Cavendish clone Pisang masak hijau, which he indicates to be the clone known in Puerto Rico as Montecristo, pointed out that it ripens slowly, unevenly, and with poor color, especially in winter. Wardlaw, Leonard, and Barnell (9) reported differences in ripening behavior of a hybrid banana harvested at grades equivalent to those used for harvesting the Gros Michel. They also reported that when the plants are infected with leaf-spot disease this may lead to premature ripening, possibly because the infection slows the development of the fruit, and, as a result, the fruit may be harvested at a more advanced physiological age than is apparent from the fullness of the fingers.

\section{MATERIALS AND METHODS}

The fruit used for these studies was harvested from experimental plots of the local cultivar known as Montecristo Gigante grown at the Fortuna Substation on the Southern Coast of Puerto Rico, and at the Adjuntas Substation on the Mountainous Region, at an elevation of 1,800 feet above sea level. The fruit was harvested at a predetermined age measured from shooting. For some experiments the fruit was obtained from commercial plantations at the stage of maturity in which the fruit is normally harvested. In these lots, maturity was judged by the fullness of the fingers.

Ripening experiments were conducted in ripening rooms of about 1,000 cubic feet with controlled temperature, humidity, and air flow. Ventilation was carried out through bunk doors provided with exhaust fans. Ethylene was applied at the rate of 1 cubic foot per 1,000 cubic feet of room volume per dosage. The bunches (stems) were hung naked in the room. In all the experiments, the fruit was placed in the ripening room the day after harvest and allowed to cool until the pulp temperature, measured with thermocouples, reached the desired ripening temperature. Ethylene was then applied at the rate indicated above. Additional doses of ethylene were applied according to the schedule of the experiment in progress.

To obtain data on carbon dioxide production and to study the behavior of selected bunches under given conditions, the bunches were hung inside 55-gallon steel drums provided with loosely fitted covers. The drums were then placed inside the ripening rooms with the temperature set as required by the experiment.

Fruits from the second hand were used for analyses. The fruit was weighed and peeled. The pulp:peel ratio was calculated from the weights of pulp and peel. All analytical determinations were made on the peeled fruit. Carbohydrates, acidity, and moisture are expressed on a fresh-pulp weight. Starch was determined by the method of Carter and Neubert (10). Reducing and total sugars were determined by the A.O.A.C. Lane-Eynon 
volumetric method (11). Acidity and $\mathrm{pH}$ were measured by the A.O.A.C. glass-electrode method (12). Moisture was determined by the vacuum-oven method (13). Carbon dioxide was determined on a sample of the air in the drums or ripening rooms with a Fyrite $\mathrm{CO}_{2}$ Analyzer ${ }^{3}$ by absorption in a $\mathrm{KOH}$ solution. Color grade of the ripe fruit was determined by comparison with the color chart published by the Fruit Dispatch Co. (3).

\section{RESULTS AND DISCUSSION}

In the early phases of these investigations, commercially harvested fruit was used. The fruit was ripened at $72^{\circ} \mathrm{F}$., and 95 percent relative humidity, with one dosage of ethylene applied 24 hours after the fruit was placed in the room. No ventilation was used, since ventilation during ripening was not a commercial practice in Puerto Rico at that time. The results of these tests were very discouraging, the fruit ripening unevenly with many of the bunches not ripening at all even after staying in the room for many days with additional dosages of ethylene.

The experiments were then directed to investigate the effect of the ethylene dosage and ventilation schedules on ripening. It was found that, even though the rooms were tight, it was necessary to apply ethylene twice within a period of 12 hours to induce ripening.

To investigate the effect of ventilation, and in order to be able to measure the carbon dioxide concentration in the atmosphere during ripening, a series of experiments was as conducted in which the bare bunches were ripened inside 55-gallon steel drums fitted with loose covers. The drums were then placed in ripening rooms under constant temperature. Ethylene was applied at the required dosage. Carbon dioxide was measured by sampling the atmosphere in the drums. To ventilate the drums, a vacuum cleaner was connected to each for a given period of time removing the air mixture inside and allowing its replacement with fresh air. Carbon dioxide concentrations in the drums were measured every 24 hours before ventilation was applied. The results from some of the tests are shown in table 1 . The second day after ethylene was applied, the carbon dioxide concentration increased appreciably and in some experiments exceeded 5 percent. Since the drums were not tightly closed some diffusion of gases from the drums was unavoidable, so that probably the concentration of carbon dioxide may have been greater than indicated. Since concentrations of carbon dioxide of about 5 percent may retard ripening (14), in order to keep the concentration below toxic levels and replenish the oxygen, ventilation would have to start the second day after the ethylene application. When ventilation was

Mention of trade names in this publication does not constitute a guarantee, warranty or endorsement of a particular instrument. Trade names are used solely for the purpose of providing specific information. 
applied for 15 minutes every day, starting 24 hours after ethylene application, ripening was much improved with a greater percentage of the bunches ripening within a period of 4 to 5 days. When the bunches were ripened in the ripening rooms, the need for daily ventilation was confirmed, although in this case, the carbon dioxide concentration in the room atmosphere remained around 0.5 percent, because the rooms were not fully loaded. Under the conditions used by some local operators to ripen the bananas, in which the rooms are overloaded, the need for ventilation is imperative, as indicated by the results of this work.

Although by applying ethylene and ventilating daily as indicated, the Montecristo bananas were ripened in 4 to 5 .days to an attractive yellow color (grade 5) and good flavor at $72^{\circ} \mathrm{F}$,' finger drop was a serious problem. Finger drop was more of a problem when the ripe fruit was placed at room temperature $\left(82^{\circ}-85^{\circ} \mathrm{F}\right.$.), or under store display temperatures $\left(76^{\circ} \mathrm{F}\right.$.).

TABLE 1.-Carbon dioxide content al several intervals during banana ripening

\begin{tabular}{c|c|c|c}
\hline \multirow{2}{*}{ Ripening temperature } & \multicolumn{3}{|c}{ Carbon dioxide content (percent) after days indicated- } \\
\cline { 2 - 4 } & 3 & 4 & 5 \\
\hline \multirow{2}{*}{$72^{\circ} \mathrm{F}}$. & 0.5 & 1.5 & - \\
& 4.7 & 3.8 & 6.0 \\
& 1.2 & 1.2 & 2.4 \\
& 1.4 & 1.0 & 1.7 \\
& 1.2 & 3.8 & 4.6 \\
\hline
\end{tabular}

Lower ripening temperatures were tried to reduce finger drop. Ripening experiments were carried out at $68^{\circ} \mathrm{F}$. and a 90 to 95 -percent relative humidity until the desired cutting color was reached, and also lowering the temperature to $66^{\circ} \mathrm{F}$. with a relative humidity of 85 percent after turning. When ripening at $68^{\circ} \mathrm{F}$., finger drop was reduced, but was still objectionable. When the temperature was lowered to $66^{\circ} \mathrm{F}$. after turning, and maintained until cutting, no appreciable finger drop resulted. Under these conditions the fruit ripened to color 4 or 5 in 6 to 7 days.

Even with this ripening treatment, in many experiments several lots of fruit ripened unevenly or did not ripen at all. This anomalous behavior was traced to the stage of maturity or grade at cutting. Fruit cut at a thin grade like "three-quarters" showed uncertain ripening characteristics, ripening unevenly, or not ripening at all. The relationship between the ripening characteristics and the stage of development at harvesting was more apparent in fruit harvested in the highlands than in fruit harvested on the Southern Coastal Plains.

Table 2 shows the results obtained in one experiment in which fruit 
harvested at different ages after shooting was ripened at $68^{\circ} \mathrm{F}$. until turning, and then the temperature was lowered to $66^{\circ} \mathrm{F}$. The fruit harvested at an age ranging from 91 to 100 days after shooting remained green after staying 7 days in the ripening room. The bunch with an age of 104 days was partly ripe and all bunches ranging in age from 110 to 155 days ripened evenly to grade 5 within this period. This relationship of age to ripening characteristics was observed in a large number of experiments which were conducted. In some experiments in which a number of bunches failed to ripen, a statistically significant difference was found between the weights of the fingers of the fruit which ripened and those which did not ripen.

TABLE 2.-Effect of age at harvesting bananas on the stage of ripeness after 7 days in ripening room at $68^{\circ}-66^{\circ} \mathrm{F}, 95-85$ percent relative humidity

\begin{tabular}{c|c|c|c}
\hline Age at harvesting & Starch & Reducing sugars & Condition of the fruit \\
\hline Days & Percent & Percent & \\
93 & 29.73 & 0.76 & Green \\
96 & 29.57 & .85 & do. \\
99 & 25.68 & 2.30 & do. \\
100 & 25.33 & .98 & do. \\
104 & 13.26 & 3.97 & Turning \\
110 & 5.31 & 1.53 & Ripe \\
113 & 4.54 & 3.97 & do. \\
117 & 1.45 & 6.22 & do. \\
123 & 1.73 & 7.30 & do. \\
133 & 2.21 & 7.62 & do. \\
138 & 1.76 & 7.12 & do. \\
142 & 1.53 & 6.98 & do. \\
155 & 1.19 & 8.05 & do. \\
\hline
\end{tabular}

In order to determine the proper stage of harvesting for the Montecristo cultivar grown in Puerto Rico, extensive studies were conducted which have been reported in two previous publications $(15,16)$. The age for harvesting to assure good ripening behavior was found to vary throughout the year with the month of flowering and harvest, and the zone in which the fruit was produced. Fruit grown at the Fortuna Substation on the Southern Coast of Puerto Rico, and harvested from April to the following January, at an age ranging from 90 to 135 days measured from shooting, could be ripened with no trouble at all. This fruit ripened in 6 to 7 days uniformly to color grade 5 , with a bright yellow color with a green tip, and with good flavor and aroma. The average age for cutting through the year was around 100 days after shooting.

When fruit was harvested in the Adjuntas Substation at an elevation of 1,800 feet above sea level, the stage of development of the bunch, and hence 
the age at harvesting for grades "light three-quarters" to "full threequarters", varied markedly with the time of flowering, ranging from 166 days for plots blooming in November to 115 to 128 days for plots blooming from April to August.

With the exception of the fruit which developed during the winter months, the fruit harvest from the Adjuntas Substation ripened satisfactorily when harvested at the proper grade, from "light three-quarters" to "full three-quarters". Fruit harvested during the winter months ripened less satisfactorily than during the summer months. The color of the ripe fruit was dull yellow, sometimes lacking the green tip at color grade 5, and the flavor was poor. During the winter months, about 15 percent of the bunches harvested ripened unevenly, apparently because of a discrepancy

Tanle 3.-Composition of the Montecristo Fruit at several stages during ripening: Average values from several tests expressed as percentage of fresh pulp weight

\begin{tabular}{l|c|c|c|c|c|c|c}
\hline \multicolumn{1}{c|}{ Item } & \multicolumn{7}{c}{ Days in ripening room } \\
\cline { 2 - 8 } & 0 & 2 & 3 & 4 & 5 & 6 & 7 \\
\hline Starch & 33.26 & 26.76 & 18.28 & 7.99 & - & 1.09 & Traces \\
Total sugars & .53 & .99 & 3.63 & 7.27 & - & 17.10 & 21.99 \\
Reducing sugars & Traces & .42 & 2.15 & 4.85 & 7.17 & 10.51 & 12.70 \\
Nonreducing sugars & .53 & .57 & 1.48 & 2.42 & - & 6.59 & 9.29 \\
Moisture & 70.7 & 70.8 & 71.2 & 72.1 & 72.5 & 74.5 & 76.0 \\
Acidity & .19 & .19 & .29 & .36 & .40 & .37 & .32 \\
pH & 5.9 & 5.7 & 4.9 & 5.0 & 4.9 & 4.8 & 4.9 \\
\hline
\end{tabular}

between the physiological and the chronological age. In general, the fruit harvested at the Adjuntas Substation during the study, which lasted for more than a year, was inferior in quality to the fruit harvested at the Fortuna Substation and ripened less satisfactorily.

The changes in starch, total and reducing sugars, nonreducing sugars, moisture, acidity, and $\mathrm{pH}$ for the Montecristo fruit during ripening are shown in table 3. It should be noted that at ripeness, reducing-sugars exceed nonreducing sugars, which is an accord with the findings of Barnell (17) who found that reducing-sugars exceeded sucrose at ripeness.

\section{SUMMARY}

Studies were conducted to determine the optimum conditions under which to ripen the Montecristo bananas grown in Puerto Rico to obtain fruit of high quality for the fresh market and for processing. When harvested at a thin grade like "three-quarters" the fruit generally ripens unevenly or may not ripen at all. The fruit must be harvested at a more 
developed stage like "light three-quarters" or "full three-quarters". The following ripening treatment gave the best results: The fruit is placed in the ripening room as soon after harvest as possible. The room controls are set to $68^{\circ} \mathrm{F}$. and 95 percent relative humidity, and the fruit cooled to a pulp temperature of $68^{\circ} \mathrm{F}$., which, in a room with adequate refrigeration capacity, takes about 12 to 24 hours. Two dosages of ethylene at the rate of 1 cubic foot per 1,000 cubic feet of room volume are applied within a period of 2 hours keeping the room tightly closed. The next day after the ethylene application, the room is ventilated for about 15 minutes, after turning, the temperature is lowered to $66^{\circ} \mathrm{F}$. and 85 percent relative humidity, ventilating every day as previously indicated until cutting color is reached. The fruit ripens to color 4 in about 6 days. Higher ripening temperatures resulted in excessive finger drop after the fruit was removed from the ripening rooms.

The ripening behavior of the bananas was found to vary with the time of the year when harvested and with the geographical zone in which they were produced. Fruit produced on the Southern Coast of Puerto Rico ripened uniformly the year around, while fruit produced in the Mountainous Area was more difficult to ripen, particularly during the winter months.

Data are given on the changes in carbohydrates, moisture, acidity, and $\mathrm{pH}$, which take place during ripening of the Montecristo bananas.

\section{RESUMEN}

Se llevó a cabo un estudio para determinar cuál es el mejor procedimiento para madurar el guineo Montecristo que se produce en Puerto Rico, con el fin de mejorar la calidad del producto que se lleva al mercado y que se usaría también para la elaboración de purés. Los datos obtenidos de este estudio indican que los guineos de la variedad Montecristo de Puerto Rico no maduran satisfactoriamente a menos que se cosechen en un estado adecuado de desarrollo. Si la fruta se cosecha en un estado de desarrollo equivalente al que se conoce en el mercado como "tres-cuartos", no madura uniformemente o puede que no madure aun cuando se deje varios días en las cámaras de madurar. Es necesario, por lo tanto, cosechar la fruta en un estado de desarrollo más avanzado que el "tres-cuartos".

El siguiente procedimiento fue el mejor para madurar el guineo Montecristo: La fruta se coloca en las cámaras lo más pronto posible después de la cosecha, ajustando la temperatura de la cámara a $68^{\circ} \mathrm{F}$. y la humedad relativa a 95 por ciento. Se deja enfriar la fruta hasta que la temperatura de la pulpa llegue a $68^{\circ} \mathrm{F}$., lo cual puede tomar de 12 a 24 horas en una cámara con suficiente capacidad para la refrigeración. Luego se aplica etileno en dos dosis a razón de 1 pie cúbico por cada 1,000 pies cúbicos de volumen en la cámara, a un intervalo de 12 horas entre las aplicaciones y se 
mantiene la cámara cerrada por 24 horas. Luego se ventila la cámara por alrededor de 15 minutos diariamente. Cuando la fruta ya ha cambiado de color tornándose parcialmente amarilla, se reduce la temperatura a $66^{\circ} \mathrm{F}$. y la humedad relativa a 85 por ciento, manteniéndose la cámara bajo estas condiciones hasta que la fruta madure al grado de color deseado. Estas condiciones permitirán que la fruta madure a un grado de color 4 en unos 6 días. Cuando la fruta se maduró a temperaturas más altas de la indicada, su desprendimiento de las manos fue excesivo.

Las características de maduración de los guineos Montecristo varió con la época del año en que se cosecharon y con la zona de producción. Los guineos que se cosecharon en la Costa Sur de Puerto Rico maduraron satisfactoriamente durante todo el año, pero no los que se cosecharon en la Región Montañosa durante los meses de invierno.

Se ofrecen datos sobre los cambios en el contenido del almidón, azúcares totales y reductoras, humedad, acidez y pH durante la maduración de la fruta bajo las condiciones indicadas.

\section{LITERATURE CITED}

1. Von Loesecke, H. W., Bananas, Interscience Publishers Inc., New York, N.Y., 39-66, 1949.

2. Simmonds, N. W., Bananas, Longmans, Green and Co. Ltd., London, England, 214-20, 1965.

3. Banana Ripening Manual, Circular No. 31, Fruit Dispatch Co., Boston, Mass., 32 pp., 1961.

4. Stevenson, C. D., Artificial colouring and ripening of fruits, Queensland Agr. J. 78: 154-65, 1954.

5. Hall, E. G., Ripening of Bananas, Food Pres. Quart. 22 (3): 65-7, 1962.

6. Von Loesecke, H. W., Bananas, Interscience Publishers Inc., New York, N.Y., 67-118, 1949.

7. Hulting, H. O. and Proctor, B. E., Changes in some volatile constituents of the bananas during ripening, storage and processing, Food Technol. 16 (10): 440-44, 1961.

8. Simmonds, N. W., Bananas; Longmans, Green and Co. Ltd., London, England, 82-4, 1965.

9. Wardlaw, C. W., Leonard, E. R., and Barnell, H. R., Metabolic and storage investigations on the banana, Low Temp. Res. Sta. Imp. College Agr., Trinidad, Memoir 11: 61 pp., 1939.

10. Carter, G. H., and Neubert, A. M., Rapid determination of starch in apples, J. Agr. Food Chem. \& (21): 1070-72, 1954.

11. Methods of Analysis of the Association of Official Agricultural Chemists, 9th. ed., Washington, D. C., 135, 426, 1960.

12. Ibid, p. 272.

13. Tbid, p. 264.

14. Wardlaw, C. W., Preliminary observations on the refrigerated gas storage of Gros Michel bananas, Low Temp. Res. Sta., Imperial College Agr., Trinidad, Memoir 15: pp. 43, 1940.

15. Sánchez Nieva, F., Colom Covas, G., Hernández, I., Bueso de Vinas, C., and 
Guadalupe, R., Studies on the production of Montecristo bananas grown on the South Coast of Puerto Rico, J. Agr. Univ. P.R. 58 (4): 1969.

16. Sánchez Nieva, F., Colom Covas, G., Hernández, I., Guadalupe R., bueso de Viñas, C: (Mrs.), Torres, A., Studies on the production of Montecristo bananas grown on the Adjuntas Region of Puerto Rico, J. Agr. Univ. P.R. 63 (34): 1969.

17. Barnell, H. R., Low Temp. Res. Sta., Imp. College Tropical Agr., Trinidad Memoir 20: 606-45, 1943. 